\title{
Survival of PIT-tagged lesser short-tailed bats (Mystacina tuberculata) through an aerial 1080 pest control operation
}

\author{
Hannah Edmonds ${ }^{1 *}$, Moira Pryde ${ }^{2}$ and Colin F.J. O’Donnell ${ }^{3}$ \\ ${ }^{1}$ Department of Conservation, PO Box 29, Te Anau 9600, New Zealand \\ ${ }^{2}$ Science and Policy Group, Department of Conservation, Private Bag 5, Nelson 7042, New Zealand \\ ${ }^{3}$ Science and Policy Group, Department of Conservation, Private Bag 4715, Christchurch 8140, New Zealand \\ *Author for correspondence (Email: hedmonds@doc.govt.nz)
}

Published online: 17 January 2017

\begin{abstract}
Introduced mammalian predators, in particular rats (Rattus spp.), are a major threat to New Zealand bat populations. Aerial application of the toxin sodium monofluoroacetate (1080) is currently the most costeffective method of controlling rats across large spatial extents. Lesser short-tailed bats (Mystacina tuberculata) may be vulnerable to secondary poisoning from 1080 because they feed on invertebrate prey on the ground that may have consumed toxic bait. We monitored individually marked bats before, during, and after an aerial 1080 operation in the Eglinton Valley, Fiordland, in December 2014 from a population that has been monitored since 2008. No symptoms of sub-lethal exposure in free ranging bats were detected and survivorship was high: 764 of the 771 marked bats $(99.1 \%)$ recorded in the pre-monitoring period were still alive one week after toxin application and a record number of 1731 marked bats were recorded emerging from a single roost tree in January 2015. One bat pup was found dead under a roost tree and 1080 was detected in muscle tissue. Any immediate impact of 1080 was assessed as minimal because the calculated annual survival rates were high (91.5\%). We conclude that survival of the population was likely enhanced by the large scale 1080 operation.
\end{abstract}

Keywords: Mystacinidae; predator control; rats; sodium monofluoroacetate; transponders

\section{Introduction}

New Zealand has only two species of native land mammals; the long-tailed bat (Chalinolobus tuberculatus) and the lesser short-tailed bat (Mystacina tuberculata). Two subspecies C. tuberculatus (South Island) and M. tuberculata tuberculata co-exist in the Eglinton Valley, Fiordland, and are listed as nationally critical and nationally endangered, respectively (O'Donnell et al. 2013). Both species are susceptible to predation from introduced mammals; feral cats (Felis catus), rats (Rattus spp.), stoats (Mustela erminea) and brushtail possums (Trichosurus vulpecula) (Daniel \& Williams 1984; Daniel 1990; O’Donnell 2000; Lloyd 2005; O'Donnell et al. 2010, 2011; Scrimgeour et al. 2012). Mortality rates of $20-30 \%$ of bat populations occur during rat irruptions (Pryde et al. 2005; O'Donnell et al. 2011) and research indicates that bat populations will benefit from the control of mammalian predators (Sedgeley \& Anderson 2000; Lloyd \& McQueen 2002; Pryde et al. 2005; O’Donnell et al. 2010, 2011).

The negative impacts of predators are pronounced in southern beech forests (Fuscospora spp., Lophozonia menziesii) where mammalian predator numbers fluctuate in relation to food availability (King 1983). The beech trees flower and seed heavily (mast) at irregular intervals, usually 3-5 years (Wardle 1984; Schauber et al. 2002). Mast years increase food supply for mice (Mus musculus) and rats, frequently causing irruptions in their populations (O'Donnell \& Phillipson 1996), which in turn results in increased food supplies and hence prolific breeding of stoats, with up to 13 young raised per female in years when rodents are abundant (King 2005). Native species including bats are then at risk from these predators and controlling them in these years has been found to be essential for their long-term survival (O'Donnell et al. 1996; Dilks et al. 2003; Pryde et al. 2005).
Although predator control is likely to be advantageous to indigenous wildlife, lesser short-tailed bats may be vulnerable to secondary poisoning during predator control operations because of their habit of feeding on insects in the ground litter, which may have consumed toxic bait. Lesser short-tailed bats are not known to feed directly on carrot or grain based toxic baits (Lloyd 1994, 2005; Lloyd \& McQueen 2000), but have been recorded consuming fruit lured paste in captivity (Beath et al. 2004). One bat is known to have died from eating fruit lured cyanide paste (Daniel 1990), and 115 bats were found dead after ingesting peanut oil lured toxic paste containing diphacinone (Dennis \& Gartrell 2015). Previous research on the non-target effects of 1080 (sodium monofluroacetate) focussing on the concentrations of 1080 in arthropods showed a lesser short-tailed bat could potentially receive a median lethal dose (LD50) of 1080 from less than $0.7 \%$ of its daily food intake of arthropods that have fed on poison baits (Lloyd \& McQueen 2000). The LD50 for a lesser short-tailed bat is $0.15 \mathrm{~g}$ (Fairweather et al. 2014).

Previous studies on lesser short-tailed bats have shown neither an acute nor long-term negative population response to the repeated use of pindone in the Eglinton Valley (O'Donnell et al. 2011) and aerial broadcast 1080 using grain-based baits in Rangataua Forest in the North Island (Lloyd \& McQueen 2002). However, pindone has been found in the guano of lesser short-tailed bats and in the liver of five dead bats in Pureora Forest (T. Thurley, Department of Conservation (DOC), unpubl. data). It is not known if the toxin killed these bats. No adverse effects were detected in lesser short-tailed bats that were monitored throughout an aerial broadcast operation using grain based brodifacoum baits on Codfish Island (Sedgeley \& Anderson 2000).

Sodium monofluoroacetate (1080) is a toxin approved for controlling brushtail possums and rats, and acts as a secondary poison for stoats that consume toxins through scavenging 
dead rodents (Murphy et al. 1999). It is an effective toxin and the majority of pest control operations using 1080 have target pest kills of greater than $80 \%$ (Fairweather et al. 2014). Compared to anti-coagulants such as pindone, diphacinone and brodifacoum, 1080 has the added benefit that it does not accumulate in the environment as the poison breaks down to non-toxic levels after coming in contact with water (Eason et al. 1993, 2011; Parfitt et al. 1994; PCE 2011, 2013).

Compulsory practice for DOC aerial 1080 operations is to pre-feed the treatment area prior to distributing toxic bait. Pre-feeding significantly increases the amount of bait eaten by rats and possums during a toxic operation by reducing bait neophobia and the consumption of sub-lethal doses (Henderson et al. 1999; O’Connor \& Matthews 1999).

Treatment areas for aerial 1080 operations by DOC are prioritised and selected on a national basis, focusing on population strongholds of nationally endangered fauna at risk from significant predator irruptions. Operations are triggered when beech seed fall is heavy and rodent footprint tracking indices predict exponential growth in rodent populations (Elliott \& Kemp 2016). On this basis, an aerial 1080 operation took place in the Eglinton Valley on 12 December 2014 to control ship rats (Rattus rattus) during a beech mast event. In this paper, we report on the survival of a large sample of lesser short-tailed bats in the valley before, during and after bait application and compare this with the annual survival rate over a 7-year monitoring period.

\section{Methods}

\section{Study area}

The study was undertaken in the Eglinton Valley, in the northwestern corner of Fiordland National Park, South Island, New Zealand $\left(44^{\circ} 58^{\prime} \mathrm{S}, 168^{\circ} 00^{\prime} \mathrm{E}\right)$. The valley has steep sides and a flat floor, $0.5-1.5 \mathrm{~km}$ wide, between c. $250-550 \mathrm{~m}$ a.s.1. Introduced grasslands cover much of the valley floor and are dominated by red fescue (Festuca rubra) and sweet vernal grass (Anthoxanthum odoratum) with remnant red tussock (Chionochloa rubra) and fescue tussock (Festuca novae-zelandiae), along with a range of indigenous bryophytes and herbs. Other valley floor communities include a number of wetland types, braided riverbeds and small areas of shrubland. Temperate southern beech forest covers glacial terraces and outwash fans on the lower hill-slopes and then rises steeply to the timberline at 1000-1200 m a.s.1. (O’Donnell et al. 2011).

Invasive animal pests such as stoats, cats, rats, and possums are controlled to protect a range of threatened native species present in the valley. The outcome of the pest control is monitored by measuring mustelid and rodent abundance, and the survival of several threatened species in the Eglinton Valley each year.

\section{Aerial 1080 operation}

In December 2014, an aerial 1080 operation was undertaken in the Eglinton Valley. In addition, a network of 5288 Philproof-Mini bait stations (Philproof Pest Control Products, Hamilton, NZ) covering 4800 ha, each filled with $400 \mathrm{~g}$ of pindone cereal pellets $(2$-g cylindrical pellets $(11 \times 18 \mathrm{~mm})$, dyed green, containing $0.5 \mathrm{~g} \mathrm{~kg}-1$ pindone; Pest Management Services, Christchurch, NZ) and Feratox ${ }^{\circledR}$ (encapsulated cyanide, Connovation, Auckland, NZ), was operational from August 2014 to February 2015.
Cereal pre-feed and 1080 poison pellets were aerially broadcast over approximately 10939 ha of the Eglinton Valley by helicopter using an under-slung bucket. GPS technology was used to apply the bait along parallel flight paths with a swath width of $210 \mathrm{~m}$. RS5 $12 \mathrm{~mm}$ cereal pellets (Animal Control Products, Wanganui, NZ) with a cinnamon lure were spread at a rate of $1 \mathrm{~kg}$ per ha as pre-feed on 28 October 2014. The same bait type with a 1080 loading of $0.15 \% \mathrm{w} / \mathrm{w}$ was applied at $1 \mathrm{~kg}$ per hectare on 12 December 2014 (Fig. 1).

\section{Monitoring bat health}

The health of bats caught at roost sites was monitored on two occasions following the 1080 operation. On 13 December 2014 bats were captured using a mist-net, a nylon net typically used for catching birds, at a colonial roosting area 2-3 hours before dawn as they returned from feeding the night following the 1080 operation. On 16 December bats were captured using a harp trap at a roost tree. A harp trap is a $2 \mathrm{~m} \times 2 \mathrm{~m}$ square frame of metal tubing that supports two banks of vertically strung monofilament fishing line. A canvas collecting bag is attached beneath the frame. Bats fly into the lines, slide down them and land in the bag at a colonial roost tree. On both occasions bats were held for 1-2 hrs in bags in situ to assess response (if any) to potential exposure to toxin. The aim was to catch more than 10 bats and record any symptoms (lethargy,

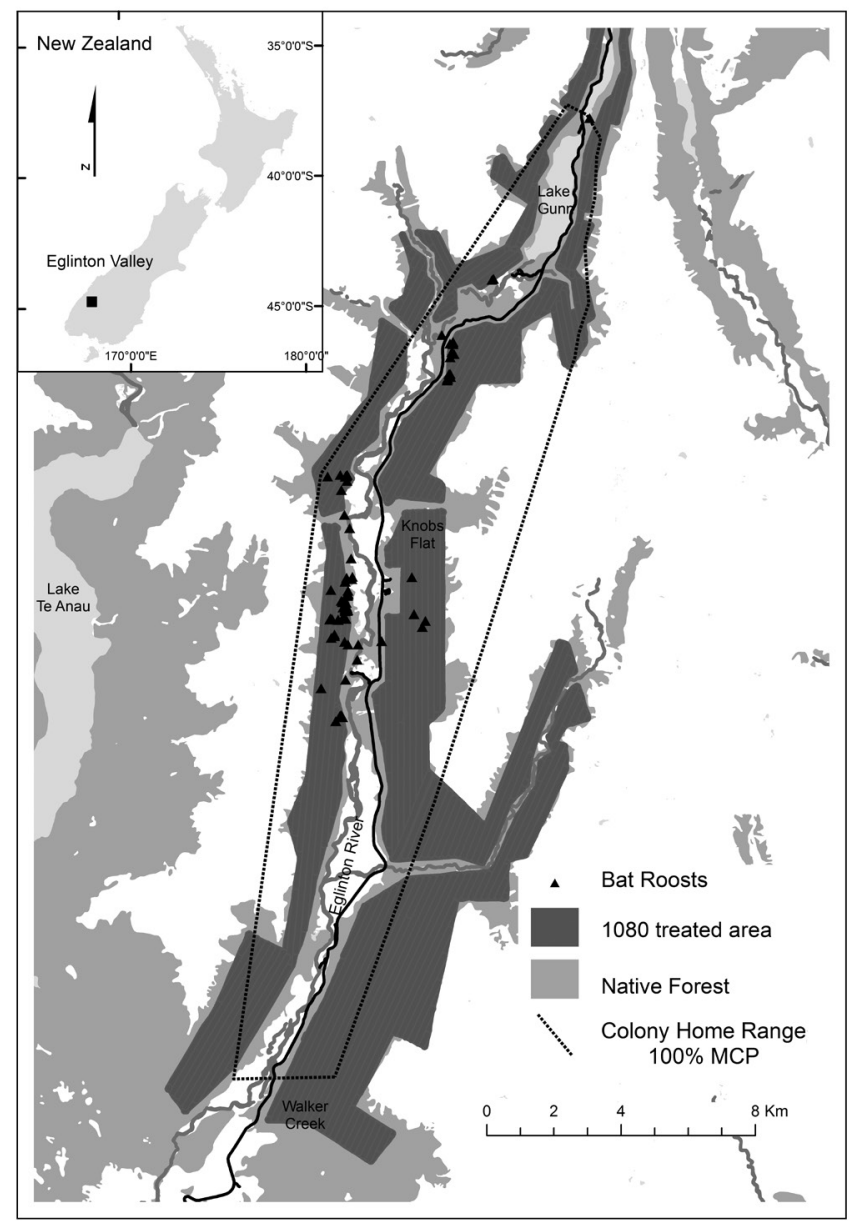

Figure 1. 1080 treatment block in the Eglinton Valley shown by the dark shaded areas. Lesser short-tailed bat roosts shown as black triangles and the dotted line represents their foraging and roosting home ranges expressed as $100 \%$ Minimum Convex Polygon (MCP) (Christie \& O’Donnell 2014). 
seizures, or signs of green dye on body). We also climbed and checked other roost sites for dead or dying bats (on ground and in roost cavities) every 3 days after the 1080 operation, until baits were deemed non-toxic. We used a wireless inspection camera (Civil Solutions, Thames, NZ) to inspect the interior of roost cavities. Activity at roosts was recorded using a custom-built infrared camera with SD recorder (Te Anau Auto Electrical, Te Anau, NZ) each night from 11 to 16 December 2014. Samples of guano were also collected at several roost sites to test for traces of 1080 toxin.

\section{Survival of bats}

Radio transmitters were attached to bats to locate roosts so that we could measure the survival of individually tagged bats. Free ranging lesser short-tailed bats were caught in a mistnet set at ground level in the middle of the roosting area at the beginning and during the pre and post poison monitoring periods. Transmitters $(0.7$ g BD2A Holohil Systems, Carp, Ontario, Canada) were attached to adult females, because they frequent colonial roosts more often than male bats. The mass of the transmitter is $<5 \%$ of the average mass of an individual bat. Transmitters were attached between the bats scapulae using a latex-based contact adhesive (F2®), Ados Chemical Co., Auckland, New Zealand) after the fur had been trimmed. Roosts were located during the day by using a TR4 receiver (Telonics, Mesa, Arizona, USA) and three-element hand-held Yagi antenna (Sirtrack, Havelock North, NZ) to radio-track the bats. Precise locations of the roost cavities in trees were determined either by the audible noises of the bats or climbing the trees with a TR4 receiver.

A total of 1738 lesser short-tailed bats have been marked with individual Passive Integrated Transponder (PIT) tags between 2006 and 2015. The PIT tags (ISO FDX-B, $11 \mathrm{x}$ $2.1 \mathrm{~mm}$ glass encased transponder; Allflex Australia Pty) were inserted subcutaneously between the bats' scapulae by trained personnel using a Henk-Ject ${ }^{\circledR}$ applicator. The identities of individually tagged bats inhabiting roost cavities were recorded during the study using radio frequency identification (RFID) data loggers and antennae at the roost entrances. Loops of antennae were shaped around the roost entrances and attached via cables to data loggers and a battery on the ground. When a PIT tag passed close to an antenna the energy of the electromagnetic field passed the individual code of the tag to the receiver where the time and date were recorded to a data file. Data loggers were downloaded every 2 or 3 days and the identity of tagged bats recorded in a database. Video cameras were also set up at the roosts to record the total number of bats emerging from the roosts.
A naïve estimate of survival was initially calculated using minimum number alive (MNA; O’Donnell 2009) before, during and after the 1080 operation on 12 December. The premonitoring period was defined as the period between 4 and 11 December. Post toxin application monitoring was conducted during three periods; 1 week after the 1080 operation from 19-31 December 2014; one month after the operation from 1 January until 2 February 2015; and 1 year later from 5-22 January 2016.

We also modelled the logging data to estimate survival rates, with datalogger recordings treated as recaptures in a robust design full likelihood $p$ and $c$ model. We estimated survival between the four data-logging time periods for males, females, adults, and first-year-bats. Recaptures were defined as any occasion when a datalogger recorded presence of individual bats entering or leaving roost cavities. The robust design model (Kendall \& Nichols 1995; Kendall et al. 1995, 1997) is a combination of the Cormack-Jolly-Seber (CJS) (Cormack 1964; Jolly 1965; Seber 1965; White \& Burnham 1999) live recapture model and the closed capture model (Otis et al. 1978). It differs from the CJS model in that instead of one re-sighting (datalogging) occasion between survival intervals, the results of multiple logging occasions are used within a short time period to meet the assumption of population closure (i.e. no mortality, immigration or emigration occurs). These supplementary logging occasions are termed secondary occasions and the longer intervals are known as the primary occasions. The power of this model is that the probability of initially identifying the animal by the dataloggers $(p)$ and the probability of identifying that animal again $(c)$ can be calculated within each logging session and then the population size $(\hat{N})$ calculated. The preferred model was selected from the candidate set of models based on the lowest AIC (Burnham \& Anderson 2003).

To ensure the desired condition of population closure, logging sessions were limited to a 7-day period before the application of toxic baits, then to a 5-day data logging session for subsequent occasions. Intervals between subsequent logging sessions were 10 days, 31 days and 352 days respectively. We modelled gender and age in the model as these factors were considered important based on previous survival studies (Pryde et al.2005) and we wanted to make sure that the effects of 1080 were not biased towards one sex or age. Bats were classed as first year if they had been born and tagged the previous season (Table 1). The probability of first identifying a bat and subsequent identifications was set as constant as there was thought to be no difference between the probability of first logging a bat on the loggers and subsequent logging events.

Table 1. MNA of PIT-tagged lesser short-tailed bats in the Eglinton Valley 2014-2016. First year bats are defined as bats born and tagged during the previous summer (i.e. January 2014). If a bat was identified as alive in later sessions but not the second it is subsequently counted in the MNA results.

\begin{tabular}{lcccc}
\hline Age - sex class & $\begin{array}{c}\text { November 2014 } \\
(\text { pre-1080) }\end{array}$ & $\begin{array}{c}\text { December 2014 } \\
(1 \text { week post-1080) }\end{array}$ & $\begin{array}{c}\text { January 2015 } \\
(1 \text { month post-1080) }\end{array}$ & $\begin{array}{c}\text { January 2016 } \\
(1 \text { year post-1080) }\end{array}$ \\
\hline Adult male & 267 & 264 & 258 & 194 \\
Adult female & 449 & 445 & 441 & 391 \\
First year male & 25 & 25 & 23 & 18 \\
First year female & 29 & 29 & 28 & 26 \\
\hline Totals & 771 & $764(99.1 \%)$ & $751(97.4 \%)$ & $630(81.7 \%)$ \\
\hline
\end{tabular}


As part of our normal annual monitoring we calculated the annual survival rate of adult female bats over 7 years (2008-2015). Only the adult female results are calculated as males have a different recapture probability over time as they do not reliably congregate in maternity roosts (O'Donnell 2000). We compared the long-term adult female survival rates with estimates during the 1080 operation. For this analysis, we use the multi-state recaptures only model that allows transition from juveniles to adults (Brownie et al. 1993; Hestbeck et al. 1991). These models are an extension of the CJS live recapture model extended to include multiple states. Our model included gender and time and the two transition states were adults and juveniles. We constrained the model so that juveniles could only transition into adults.

\section{Results}

\section{Short term survival}

Five female lesser short-tailed bats had transmitters attached to them during November and December 2014 and were tracked to six communal roost trees. A total of 771 PIT-tagged bats were recorded from these roosts prior to the 1080 operation between 27 November and 12 December 2014, and 764 of these were alive 1 week following the 1080 operation (using data from 19/12/2014-28/12/15). Thus a minimum of $99.1 \%$ were alive after 1 week (Table 1 ).

The survival analyses included the covariates: gender, number of days between the logging sessions (time), and the age of the bats. The best survival model, selected based on the lowest AIC, depended only on time and did not include age or sex (Table 2). Survival appeared to drop in the first week after the 1080 drop, but increased one month later and remained high the following year. A similar pattern was also seen in the naïve MNA results (Fig. 2). The model to test whether the first survival period was significantly lower than the second or third time periods received little support (AIC $>10$, Model 3, Table 2).

\section{Long term annual survival estimates}

Annual survival of adult females between 2008 and 2015 was high with the exception of 2008 when annual survival was significantly lower than average (Fig. 3). The survival rate in the 2015 season following the 1080 operation was 0.915 , which was above the average survival rate of 0.83 (Fig. 3) over the 7-year monitoring period.

\section{Monitoring bat health}

Faecal samples were obtained from an easily accessible roost tree consistently occupied by a large number of bats during November and December 2014. These were tested for traces of 1080 , with no traces found. In addition, all roosts occupied after the 1080 operations were searched for dead or dying bats using a roost scope camera. No dead or dying bats were found at these roosts except one dead baby bat, with placenta still attached. This bat tested positive for 1080 with a result of $0.013 \mu \mathrm{g} \mathrm{g}^{-1} 1080$ in muscle tissue.

We caught bats returning to roost trees on two occasions

Table 2. Models describing the effect of survival (ø) and recapture probability $(p)$ of lesser short-tailed bats in the Eglinton Valley using Program MARK. AIC = Akaike Information Criteria, ML = model likelihood, NP = number of parameters.

\begin{tabular}{|c|c|c|c|c|c|c|}
\hline Model & $\mathrm{AIC}$ & $\Delta \mathrm{AIC}$ & weight & $\mathrm{ML}$ & NP & Deviance \\
\hline 1. Survival dependent on time & -3632.32 & 0 & 0.984 & 1 & 117 & 9964.03 \\
\hline 2. Survival constant & -3622.55 & 9.77 & 0.007 & 0.0076 & 121 & 9965.54 \\
\hline $\begin{array}{l}\text { 3. Survival different in the first week } \\
\text { compared to other time periods }\end{array}$ & -3622.01 & 10.31 & 0.005 & 0.0058 & 122 & 9964.03 \\
\hline 4. Survival dependent on gender & -3620.51 & 11.82 & 0.003 & 0.0027 & 122 & 9965.53 \\
\hline 5. Survival dependent on gender and time & -3613.92 & 18.40 & 0.0001 & 0.0001 & 126 & 9963.85 \\
\hline 6. Survival dependent on time age and gender & -3603.3 & 29.02 & 0 & 0 & 132 & 9962.07 \\
\hline
\end{tabular}

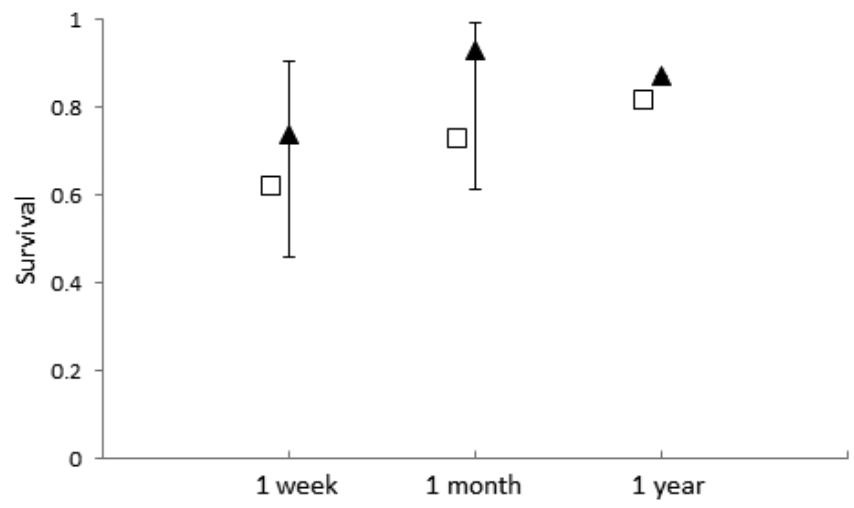

Figure 2. Apparent survival of all marked bats after the 1080 drop ( 1 week, 1 month and 1 year) with $95 \%$ confidence intervals compared with the survival of all bats estimated by minimum number alive (survival $=$ triangles, $\mathrm{MNA}=$ squares).

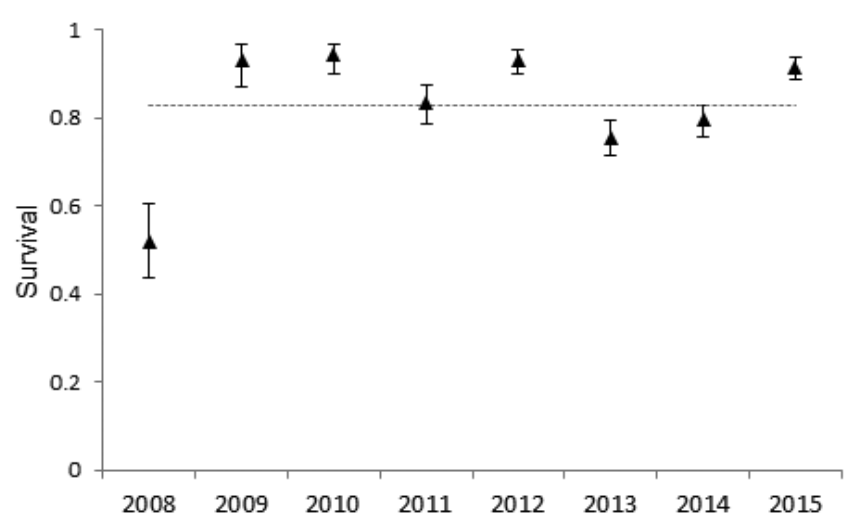

Figure 3. Annual survival of adult females (2008-2015) with $95 \%$ confidence intervals - the grey dotted line (survival $=0.83$ ) represents the average survival rate since the project commenced. 
directly after the 1080 operation. On 13 December at 3 am, 11 bats were captured in a mist net near occupied roost trees; none showed signs of poisoning and appeared healthy. On 16 December at 2 am, 19 bats were caught flying back into a communal roost using a harp trap. Again none showed signs of poisoning. Video recording at roosts did not show any abnormal behaviour and counts of emerging lesser short-tailed bats recorded the highest ever count (since 1997) of 1731 bats emerging from a roost.

\section{Discussion}

Survival of lesser short-tailed bats in the Eglinton Valley was higher than average after the 1080 operation, and we recorded the highest roost count since annual counts began in 1997. At least $99.1 \%$ of the individually marked lesser short-tailed bats recorded alive immediately prior to application of 1080 in December 2014 were still alive 1 week after the operation, and $97.4 \%$ of the original bats monitored were still alive one month later. These figures underestimate survival because (a) not all bats will visit the monitored roosts (particularly males in the breeding season), (b) the RFID antennae do not always detect PIT tagged bats as they pass and (c) there may be some tag loss as has been seen in other areas (J. Sedgeley, T. Thurley, pers. comm.). Tag loss is a problem at the North Island lesser short-tailed bat monitoring site (Pureora) with at least 40 tags dropped out of 923 bats that had been tagged over a period of 1-393 days since insertion (T. Thurley, pers. comm.). A search for dropped tags was made at accessible roosts in the Eglinton Valley and one tag was discovered. The number of tags lost and reasons for it requires further investigation because if a significant number of tags are being lost then it will affect confidence in the survival rates.

Modelling of adult female survival with the robust model pre and post the 1080 operation showed that any initial decline in survival was more than compensated by high monthly and yearly survival. Annual survival was higher than average when compared to previous years when 1080 was not deployed (Pryde et al. 2005). Survival was higher than that recorded for many other bat species (Tuttle \& Stevenson 1982). Low survival in the 2008 season was when there were high predator numbers in the study area following a heavy beech mast and predator management occurred over a small part of the known lesser short-tailed bat habitat.

Observations of bats at roosts showed no adverse immediate effects from the toxin, however, there was one dead baby bat that had traces of 1080 detected in the muscle tissue. It is not known if the 1080 caused the death of this young bat. The 1080 must have entered the system of the mother and may have been passed onto the young via the mother's bloodstream. Continued monitoring is required on an annual basis to test whether there are any long-term sub lethal effects of this poison; however, one year after the 1080 operation there is no evidence to show any adverse population effects.

This is the first study to observe the response of a high proportion of individually marked lesser short-tailed bats to an aerial 1080 cereal pellet rodent control operation. Previous studies of potential effects of 1080 on bats were operations designed for controlling brushtail possums at a much higher bait sowing rate than was used in the Eglinton Valley. Furthermore, the possum-control operation monitored a smaller number of unmarked bats returning to a roost one night after bait deployment (Lloyd \& McQueen 2002).
The above average survival rates of adult females for the 2015 Eglinton Valley operation was higher than expected and we suggest that this reflects the success of the 1080 operation. Numerous forest wildlife species in New Zealand are at risk of extinction as a result of the impacts of introduced mammalian predators (Innes et al. 2010). Aerial applications of toxins play an essential role in landscape-level control of introduced predators aimed at recovering fauna populations (Miller \& Anderson 1992; Innes et al. 1999; O’Donnell \& Hoare 2012). Long-term predator control, particularly for rats will be required to ensure the persistence of New Zealand bats (Molloy 1995; O’Donnell et al. 2010). Monitoring the effect of aerial applications of 1080 in areas with lesser short-tailed bats should be standard practice, due to their threat status and because there has been limited investigation of individual fates of species during 1080 operations (Veltman et al. 2014).

\section{Acknowledgements}

Thank you to Jane Sedgeley for pioneering the PIT-tag work for lesser short-tailed bats and Stu Cockburn for the development of the RFID electronic equipment. Dane Simpson and Jeremy Knowles custom built the video cameras. The main field work was done by Warren Simpson, Jane Tansell and Sanjay Thakur, and the following people assisted with catching and processing bats: Rose Colhoun, Chloe Corne, Zenon Czenze, Terry Greene, Athena Irvine, Rebecca Jackson, Monique Jansen van Rensburg, Shinji Kameyama, Gerald Kerth, Linda Kilduff, Peter Kirkman, Jasmine Ledgard, Phillip Marsh, Lara McBride, Afrika McNall, Moritz Mueller, Emmanuel Oyston, Sophie Penniket, Lucy Rossiter, Ann Schlesselmann, Scott Simmons, Dane Simpson, Rebecca Stevens, Jason van de Wetering, Mihoko Wada and John Whitehead. Paul van Dam Bates and Richard Barker gave valuable statistical advice. Thank you to Terry Greene, Emmanuel Oyston and two anonymous reviewers for helpful comments that greatly improved the manuscript.

\section{References}

Beath A, Thorne J, Robertson AW 2004. Evaluating the attractiveness of pest-control baits and lures to captive short-tailed bats, Mystacina tuberculata. Department of Conservation Science Internal Series 189. Wellington, Department of Conservation. $19 \mathrm{p}$.

Brownie C, Hines JE, Nichols JD, Pollock KH, Hestbeck JB 1993. Capture-recapture studies for multiple strata including non-Markovian transitions. Biometrics 49: 1173-1187.

Burnham K, Anderson DR 2003. Model selection and multimodel inference: a practical information-theoretic approach. 2nd edn. Springer Science and Business Media. $488 \mathrm{p}$.

Christie JE, O’Donnell CFJ 2014. Large home range size in the ground foraging bat, Mystacina tuberculata, in cold temperate rainforest, New Zealand. Acta Chiropterologica 16: 369-377.

Cormack RM 1964. Estimates of survival from the sighting of marked animals. Biometrika 51: 429-438.

Daniel MJ 1990. Bats: order Chiroptera. In: King CM ed. Handbook of New Zealand mammals. Auckland, Oxford University Press. Pp. 114-137. 
Daniel MJ, Williams GR 1984. A survey of the distribution, seasonal activity, and roost sites of New Zealand bats. New Zealand Journal of Ecology 7: 9-25.

Dennis GC, Gartrell BD 2015. Nontarget mortality of New Zealand lesser short-tailed bats (Mystacina tuberculata) caused by diphacinone. Journal of Wildlife Diseases 51: $177-186$.

Dilks P, Willans M, Pryde M, Fraser I 2003. Large scale stoat control to protect mohua (Mohoua ochrocephala) and kaka (Nestor meridionalis) in the Eglinton Valley, Fiordland, New Zealand. New Zealand Journal of Ecology 27: 1-9.

Eason CT, Gooneratne R, Wright GR, Pierce R, Frampton CM 1993. The fate of monofluoroacetate (1080) in water, mammals and invertebrates. Proceedings of the New Zealand Plant Protection Conference 46: 297-301.

Eason C, Miller A, Ogilvie S, Fairweather A 2011. An updated review of the toxicology and ecotoxicology of sodium fluoroacetate (1080) in relation to its use as a pest control tool in New Zealand. New Zealand Journal of Ecology 35: $1-20$.

Elliott G, Kemp J 2016. Large scale pest control in New Zealand beech forests. Ecological Management and Restoration 17: 200-209.

Fairweather AAC, Broom KG, Fisher P 2014. Sodium monofluoroacetate pesticide information review version 2014/1. Hamilton, New Zealand, Department of Conservation. $112 \mathrm{p}$.

Henderson RJ, Morgan DR, Frampton CM 1999. Avoiding bait-shyness in possums by improving bait standards. Report prepared for the Animal Health Board. Lincoln, Manaaki Whenua Press. 5 p.

Hestbeck JB, Nichols JD, Malecki RA 1991. Estimates of movement and site fidelity using mark-resight data of wintering Canada geese. Ecology 72: 523-533.

Innes J, Hay R, Flux I, Bradfield P, Speed H, Jansen P 1999. Successful recovery of North Island kokako Callaeas cinerea wilsoni populations, by adaptive management. Biological Conservation 87: 201-214.

Innes J, Kelly D, Overton JMcC, Gillies C 2010. Predation and other factors currently limiting New Zealand forest birds. New Zealand Journal of Ecology 34: 86-114.

Jolly GM 1965. Explicit estimates from capture-recapture data with both death and immigration stochastic model. Biometrika 52: 225-247.

Kendall W, Nichols JD 1995. On the use of secondary capturerecapture samples to estimate temporary emigration and breeding proportions. Journal of Applied Statistics 22: 751-762.

Kendall W, Pollock KH, Brownie C 1995. A likelihood-based approach to capture-recapture estimation of demographic parameters under the robust design. Biometrics 51: 293-308.

Kendall WL, Nichols JD, Hines JE 1997. Estimating temporary emigration using capture-recapture data with Pollock's robust design. Ecology 78: 563-578.

King CM 1983. The relationship between beech (Nothofagus sp.) seedfall and populations of mice (Mus musculus) and the demographic and dietary responses of stoats (Mustela erminea) in three New Zealand forests. Journal of Animal Ecology 52: 414-466.

King CM 2005. The handbook of New Zealand mammals. Oxford University Press. $610 \mathrm{p}$.

Lloyd BD 1994. Evaluating the potential hazard of aerial 1080 poison operations to short-tailed bat populations.
Conservation Science Advisory Notes No. 108. Wellington, New Zealand, Department of Conservation. $12 \mathrm{p}$.

Lloyd BD 2005. Lesser short-tailed bat. In: King CM ed. The handbook of New Zealand mammals. 2nd edn. Melbourne, Oxford University Press. Pp. 111-126.

Lloyd BD, McQueen SM 2000. An assessment of the probability of secondary poisoning of forest insectivores following an aerial 1080 possum control operation. New Zealand Journal of Ecology 24: 47-56.

Lloyd BD, McQueen 2002. Measuring mortality in shorttailed bats (Mystacina tuberculata) as they return from foraging after an aerial 1080 possum control operation. New Zealand Journal of Ecology 26: 53-59.

Miller CJ, Anderson S 1992. Impacts of aerial 1080 poisoning on birds of Rangitoto Island, Hauraki Gulf, New Zealand. New Zealand Journal of Ecology 16: 103-107.

Molloy J 1995. Bat (peka peka) recovery plan (Mystacina, Chalinolobus). Threatened Species Recovery Plan Series 15. Wellington, Department of Conservation. $24 \mathrm{p}$.

Murphy EC, Robbins L, Young JB, Dowding JE 1999. Secondary poisoning of stoats after an aerial 1080 poison operation in Pureora Forest, New Zealand. New Zealand Journal of Ecology 23: 175-182.

O’Connor CE, Mathews LR 1999. 1080-induced bait aversions in wild possums: influence of bait characteristics and prevalence. Wildlife Research 26: 375-381.

O'Donnell CFJ 2000. Conservation status and causes of decline of the threatened New Zealand long-tailed bat Chalinolobus tuberculatus (Chiroptera: Vespertilionidae). Mammal Review 30: 89-106.

O'Donnell CFJ 2009. Population dynamics and survivorship in bats. In: Kunz TH, Parsons S eds. Ecological and behavioral methods for the study of bats. 2nd edn. Baltimore, Johns Hopkins University Press. 901 p.

O’Donnell CFJ, Hoare JM 2012. Quantifying the benefits of long-term integrated pest control for forest bird populations in a New Zealand temperate rainforest. New Zealand Journal of Ecology 36: 131-140.

O’Donnell CFJ, Phillipson SM 1996. Predicting the occurrence of mohua predation from the seedfall, mouse and predator fluctuations in beech forests. New Zealand Journal of Zoology 23: 287-294.

O’Donnell CFJ, Dilks PJ, Elliott GP 1996. Control of a stoat Mustela erminea population irruption to enhance mohua (yellowhead) Mohoua ochrocephala breeding success in New Zealand. New Zealand Journal of Zoology 23: 279-286.

O’Donnell CFJ, Christie JE, Hitchmough RA, Lloyd B, Parsons S 2010. The conservation status of New Zealand bats, 2009. New Zealand Journal of Zoology 37: 297-311.

O'Donnell CFJ, Edmonds H, Hoare JM 2011. Survival of PIT-tagged lesser short-tailed bats (Mystacina tuberculata) through a pest control operation using the toxin pindone in bait stations. New Zealand Journal of Ecology 35:291-295.

O'Donnell CFJ, Christie JE, Lloyd B, Parsons S, Hitchmough RA 2013. Conservation status of New Zealand bats, 2012. New Zealand Threat Classification Series 6. Wellington, New Zealand, Department of Conservation. 8 p.

Otis DL, Burnham KP, White GC, Anderson DR 1978. Statistical inference from capture data on closed animal populations. Wildlife Monographs 62: 3-135.

Parfitt RL, Eason CT, Morgan AJ, Wright GR, Burke CM 1994. The fate of monofluoroacetate (1080) in soil and water. In: Seawright AA, Eason CT eds. Proceedings of 
the Science Workshop in 1080. Miscellaneous Series 28. Wellington, the Royal Society of New Zealand. Pp. 59-66.

PCE 2011. Evaluating the use of 1080: predators, poisons and silent forests. Wellington, New Zealand, Parliamentary Commissioner for the Environment. 85 p.

PCE 2013. Update report. Evaluating the use of 1080: predators, poisons and silent forests. Wellington, New Zealand, Parliamentary Commissioner for the Environment. 15 p.

Pryde MA, O'Donnell CFJ, Barker RJ 2005. Factors influencing survival and long-term population viability of New Zealand long-tailed bats (Chalinolobus tuberculatus): implications for conservation. Biological Conservation 126: 175-185.

Schauber EM, Turchin P, Simon C, Kelly D, Lee WG, Allen RB, Payton IJ, Wilson PR, Cowan PE, Brockie RE 2002. Masting by eighteen New Zealand plant species: the role of temperature as a synchronising cue. Ecology 83: 1214-1225.

Scrimgeour J, Beath A, Swanney M 2012. Cat predation of short-tailed bats (Mystacina tuberculata rhyocobia) in Rangataua Forest, Mount Ruapehu, central North Island, New Zealand. New Zealand Journal of Zoology 39: 257-260.

Editorial board member: David Pattermore

Received 27 May 2016; accepted 28 November 2016
Seber GAF 1965. A note on the multiple recapture census. Biometrika 52: 249-259.

Sedgeley J,Anderson M 2000. Capture and captive maintenance of short-tailed bats on Codfish Island and monitoring of wild bats during the kiore eradication programme, winter 1998. Invercargill, Department ofConservation Southland Conservancy. $64 \mathrm{p}$.

Tuttle MD, Stevenson D 1982. Growth and survival of bats. In: Kunz TH ed. Ecology of bats. New York, Plenum Press. Pp. 105-150.

Veltman CJ, Westbrooke IM, Powlesland RG, Greene TC 2014. A principles-based decision tree for future investigations of native New Zealand birds during aerial 1080 operations. New Zealand Journal of Ecology 38: 103-109.

Wardle JA 1984. The New Zealand beeches, ecology, utilisation and management. Christchurch, New Zealand, New Zealand Forest Service. 447 p.

White GC, Burnham KP 1999. Program MARK: survival estimation from populations of marked animals. Bird Study 46: Supplement. 120-138. 